\title{
Genetic Resources and Adaptive Management of Conifers in a Changing World
}

\author{
Csaba Mátyás
}

check for

Citation: Mátyás, C. Genetic Resources and Adaptive

Management of Conifers in a Changing World. Forests 2021, 12, 1213. https://doi.org/10.3390/ f12091213

Received: 31 August 2021

Accepted: 2 September 2021

Published: 6 September 2021

Publisher's Note: MDPI stays neutral with regard to jurisdictional claims in published maps and institutional affiliations.

Copyright: (C) 2021 by the author. Licensee MDPI, Basel, Switzerland. This article is an open access article distributed under the terms and conditions of the Creative Commons Attribution (CC BY) license (https:// creativecommons.org/licenses/by/ $4.0 /)$.
NEESPI Regional Focus Research Center for Nonboreal Eastern Europe, Institute of Environmental and Geosciences, Faculty of Forestry, University of Sopron, P.O. Box 132, H-9401 Sopron, Hungary; matyas.csaba@uni-sopron.hu

Human activities have widely exploited and transformed the resources of coniferous species and ecosystems. The global threat of climate change further amplifies their vulnerability. There is an urgent need to support their resilience and to conserve genetic resources in order to maintain their adaptive potential.

Climatic change causes a mismatch between tree populations in the sites they occupy in the future and the climate to which they have adapted in the past. The maintenance of productivity, carbon sequestration, ecological and societal services require stable populations and ecosystems. The response of conifer species to worsening climatic scenarios is still insufficiently investigated, particularly at the vulnerable trailing (xeric) range limits. Management strategies require more information on their adaptive and evolutionary capacity. Provenance tests are obvious sources, providing valuable details on the performance of populations planted in diverse environments. Unsurprisingly, the majority of papers in this Special Issue utilize their results, pondering the odds of matching seed sources with projected climates, to increase resilience and prevent extinction.

The papers have disparate geographical and climatic backgrounds, from Central and Northwestern Europe, the Mediterranean, Russia, China, and North and Central America. They represent very diverse approaches, which was the aim of the guest editor.

Selective effects of extreme habitats have also maintained high genetic and phenotypic diversity among isolated, peripheral populations [1]. Due to the high survival risks, extreme conditions require careful management planning [2]. Detailed studies clearly indicate that differences in stability are genetically controlled, but local site interactions may be unpredictable [3]. Soil conditions can mask climate effects, and a separated analysis is proposed to better interpret their interaction [4].

The unique potential of provenance tests is illustrated by the results of trial networks; response projections are less dramatic than those provided by inventory data analyses [5]. In mountainous terrain, shifting trees upwards in altitude to compensate for climatic warming appears to be a feasible management action [6]. When selecting the proper provenance for assisted migration, the choice of a single population should be preferred over admixtures and composite methods [7]. Seed weight increases with the warming climate, improving seedling survival. This trait should also be considered, especially on extreme sites [8]. Some further queries for assisted migration are the transfer of populations outside their current natural distribution, selective breeding for disease-resistant trees, differentiation of measures according to the position in the range of the species, or the invasive potential of transferred species, etc. Research into these issues requires multiple field trials in disparate climates that contain populations from a representative range of habitats $[9,10]$.

Funding: This research received no external funding.

Informed Consent Statement: Not applicable.

Conflicts of Interest: The author declares no conflict of interest. 


\section{References}

1. Palla, B.; Ladányi, M.; Cseke, K.; Buczkó, K.; Höhn, M. Wood anatomical traits reveal different structure of peat bog and lowland populations of Pinus sylvestris L. in the Carpathian region. Forests 2021, 12, 494. [CrossRef]

2. Jandl, R.; Kindermann, G.; Foldal, C.; Schüler, S.; Bouissou, C. Early Performance of Tree Species in a Mountain Reforestation Experiment. Forests 2021, 12, 256. [CrossRef]

3. Skrøppa, T.; Steffenrem, A. Performance and Phenotypic Stability of Norway Spruce Provenances, Families and Clones Growing Under Diverse Climatic Conditions in Four Nordic Countries. Forests 2021, 12, 230. [CrossRef]

4. Feng, L.; Sun, J.; Shi, Y.; Wang, G.; Wang, T. Predicting Suitable Habitats of Camptotheca acuminata Considering Both Climatic and Soil Variables. Forests 2021, 11, 891. [CrossRef]

5. Mátyás, C.; Beran, F.; Dostál, J.; Čáp, J.; Fulín, M.; Vejpustková, M.; Božič, G.; Balázs, P.; Frýdl, J. Surprising Drought Tolerance of Fir (Abies) Species Between Past Climatic Adaptation and Future Projections Reveals New Chances for Adaptive Forest Management. Forests 2021, 12, 821. [CrossRef]

6. Cruzado-Vargas, A.L.; Blanco-García, A.; Lindig-Cisneros, R.; Gómez-Romero, M.; Lopez-Toledo, L.; de la Barrera, E.; SáenzRomero, C. Reciprocal Common Garden Altitudinal Transplants Reveal Potential Negative Impacts of Climate Change on Abies religiosa Populations in the Monarch Butterfly Biosphere Reserve Overwintering Sites. Forests 2021, 12, 69. [CrossRef]

7. Notivol, E.; Santos del Blanco, L.; Chambel, R.; Climent, J.; Alía, R. Seed Sourcing Strategies Considering Climate Change Forecasts: A Practical Test in Scots Pine. Forests 2021, 11, 1222. [CrossRef]

8. Parfenova, E.I.; Kuzmina, N.A.; Kuzmin, S.R.; Tchebakova, N.M. Climate Warming Impacts on Distributions of Scots Pine (Pinus sylvestris L.) Seed Zones and Seed Mass Across Russia in the 21st Century. Forests 2021, 12, 1097. [CrossRef]

9. Sáenz-Romero, C.; O’Neill, G.; Aitken, S.N.; Lindig-Cisneros, R. Assisted Migration Field Tests in Canada and Mexico: Lessons, Limitations, and Challenges. Forests 2021, 12, 9. [CrossRef]

10. Rehfeldt, G.E.; Warwell, M.V.; Monserud, R.A. Species, Climatypes, Climate Change, and Forest Health: A Conversion of Science to Practice for Inland Northwest (USA) Forests. Forests 2021, 11, 1237. [CrossRef] 